\title{
O CORPO DE UMA LINHA E O OPERARI- ADO DO SILÊNCIO: AVIVAR NA LÍNGUA A POTÊNCIA DO NÃO-DITO
}

por Isadora Machado[2]

As próprias palavras transpiram silêncio.

Eni Orlandi

O corpo de uma linha $\lcm{37}$ é o livro de estréia do também poeta Marcos A. Ramos. Já de início, o título nos toma de assalto e, imagino, caso o visse numa vitrine de livraria, o leitor já se sentiria perturbado. O corpo de uma linha, o corpo de uma linha... - ressoariam insistentes os sentidos múltiplos. De todo modo, no título já há um sinal: trata-se também da palavra poemática que se inscreve no corpo navalhado insistentemente pela letra. E em nada disso há abstração: nem na palavra, que é pedra insistentemente talhada pelo poeta; e nem no corpo, que é lugar febril de inscrita daduvidosa prosa.

O livro, em princípio, perpassa diversos temas que se alinham por um mesmo gesto: agir com/n'/sobre/sob o silêncio fundador[4]. O corpo de uma linha é uma obra que atua de modo cuidadoso no limite da palavra-som e da palavra-forma. M. A. Ramos se coloca, nesse sentido, como um operário do silêncio e consegue, como propõe, "compreender a nota no corpo morto/da composição".[5] O exercício, nesse caso, "é avivar na língua/a potência do não-dito".[6]

A palavra que funda, faz. E, ao fazer, quer "saber de cor o silêncio/ - e profaná-lo, dissolvê-lo/em palavras", como lembra a epígrafe de Orides Fontela. E a epígrafe não é apenas recurso estético de filiação, mas prenúncio. Profanar o silêncio, tirá-lo de seu lugar místico e fazer dele instrumento. A tensão insistente causada pela vontade de deslustrar a página em branco é matéria-prima de trinta e oito poemas muito bem dispostos.

O primeiro poema do livro, O exercício do verso, já expõe o quadro febril do corpo: se antes tocado pela ausência, agora é o fluxo da palavra que o toca e faz dele morada da letra. Seja a manhã exata, seja o pulso desatado, tudo isso, lembra o poeta, conflui à palavra. 
Na confluência do fluido, no "desconforto/ incessante que habita/ o museu de tudo"[7], em todo curso, uma direção que "sabe/a insuficiência de manter/passos de prosseguir”.[8] Insuficiência que não é, de modo algum, errância. Em O corpo de uma linha, a palavra sabe de sua insuficiência diante da latência de sentido que pulsa no silêncio.

Há algum tempo já nos disse E. Orlandi que "há uma dimensão do silêncio que remete ao caráter de incompletude da linguagem: todo dizer é uma relação fundamental com o nãodizer".[9] Desse modo, Ramos compõe "no silêncio resignado de ausências"[10], agindo na incompletude da linguagem e produzindo significação. Para Orlandi, o lugar da incompletude não é o lugar dos “acidentes de linguagem”. Assim também para Ramos: “a propriedade poemática/de um tenso silêncio/se anuncia não na fratura espessa/do trauma cravado no verso/mas na duvidosa prosa/inscrita em corpo".[11]

Em Os povos, silenciar os sentidos táteis é vivificar os sentidos hábeis do corpo na medida em que este é inscrito pela letra. Sempre rever o desejo e transmudá-lo da palavraperene será "hesitar o peso da morada".[12] Nunca estacionar o sentido, já que ele "não pára; ele muda de caminho". [13] Mudar de caminho, para Ramos, é permanecer unicamente "na voracidade da fome que não me detém".[14]

Traçando um paralelo com o tempo em latim, E. Orlandi explica que "a palavra imprime-se no contínuo significante do silêncio e ela o marca, o segmenta e o distingue em sentidos discretos, constituindo um tempo (tempus) no movimento contínuo (aevum) dos sentidos no silêncio". 15$]$ M. A. Ramos age exatamente nocontínuo significante do silêncio, como se esse contínuo fosse uma corda firmemente estendida e que, por isso, ressoa sempre, dando o tom para que a palavra surja.

O dedo mínimo tateia o movimento contínuo do silêncio, fazendo com que possamos ouvir a segmentação do sentido: música de sobrevivência. O dedo mínimodo poeta ora inaugura o verso, ora "em superfície porosa/antecipa o som monocórdico".[16] O silêncio mínimo passa a estar também “o ventre que já não oculta/qualquer perene sensação”.[17]

Ao ser preciso na escolha do que não será dito, M. A. Ramos permite que os poemas se abram a inúmeras significações. Ao ser preciso na escolha do que é dito, o poeta permite a exaltação do mínimo e, com isso, "pára o movimento/sem coalhar a paisagem/que se desenha no olho".[18] 
Em $O$ corpo de uma linha, o corpo é também paisagem. Paisagem nunca imóvel, já que sempre um corpo contemporâneo. Ao navalhar o corpo das linhas, nosso poeta estre[1]ante converte corpo em poema, linha em verso. A poesia, essa fica por conta do silêncio que habita todo o resto.

\section{REFERÊNCIAS}

ORLANDI, E. As formas do silêncio: no movimento dos sentidos. 6. ed. Campinas: Ed. Unicamp, 2007.

RAMOS, M. A. O corpo de uma linha. (mimeo).

[1] Este trabalho foi realizado com o auxílio do Conselho Nacional de Pesquisa (CNPq).

[2] Isadora Machado é graduada em Letras-Português pela Universidade Federal do Espírito Santo e mestranda em Lingüística pela Universidade Estadual de Campinas. Sob orientação do Prof. Dr. Eduardo Guimarães, trabalha na área de História das Idéias Lingüísticas e desenvolve o projeto de dissertação "Para além das palavras e das coisas: Friedrich W. Nietzsche e as Ciências da Linguagem".

[3] RAMOS, M. A. O corpo de uma linha. (mimeo.)

[4] "[...] o silêncio não é mero complemento de linguagem. Ele tem significância própria. E quando dizemos fundador estamos afirmando esse seu caráter necessário e próprio. Fundador não significa aqui ‘originário', nem o lugar do sentido absoluto. Nem tampouco que haveria, no silêncio, um sentido independente, auto-suficiente, preexistente. Significa que o silêncio é garantia do movimento de sentidos." ORLANDI, E. As formas do silêncio -no movimento dos sentidos. 6. ed. Campinas: Editora da Unicamp, 2007, p.13.

[5] RAMOS, M. A. A. In: O corpo de uma linha. (mimeo). P.12.

[6] Ibid.

[7] RAMOS, M. A. Passos de prosseguir. In: O corpo de uma linha. (mimeo). P. 10.

[8] Ibid.

[9] ORLANDI, E. As formas do silêncio- no movimento dos sentidos. 6. ed. Campinas: Editora da Unicamp, 2007, p.12.

[10] RAMOS, M. A. A. In: O corpo de uma linha. (mimeo). P. 12.

[11] RAMOS, M. A. Inscrita em corpo. In: O corpo de uma linha. (mimeo). P. 26.

[12] RAMOS, M. A. Os povos. In: O corpo de uma linha. (mimeo). P. 17.

[13] ORLANDI, E. As formas do silêncio -no movimento dos sentidos. 6. ed. Campinas: Editora da Unicamp, 2007. P. 13.

[14] RAMOS, M. A. O lugar que me reconheço. In: O corpo de uma linha. (mimeo). P. 18.

[15] ORLANDI, E. As formas do silêncio -no movimento dos sentidos. 6. ed. Campinas: Editora da Unicamp, 2007, p. 25.

[16] RAMOS, M. A. O dedo mínimo (b). In: O corpo de uma linha. (mimeo).. P. 14.

[17] RAMOS, M. A. O dedo mínimo (c). In: O corpo de uma linha. (mimeo).. P. 15.

[18] RAMOS, M. A. A. In: O corpo de uma linha. (mimeo). P. 12. 